\author{
Jakub KOŚCIÓŁEK \\ Uniwersytrt Jagielloński \\ jakub.kosciolek@interkulturalni.pl
}

\title{
POLITYKA INTEGRACYJNA MNIEJSZOŚCI ROMSKIEJ W SZWECJI - MODEL I DOBRE PRAKTYKI
}

\footnotetext{
ABSTRACT Swedish Roma Integration Policy - Model and Good Practicies

Sweden is inhabited by the biggest Roma people population among Nordic countries. The community is however very diverse in reference regarding the language spoken, the belief, and origin. For years this particular minority had been marginalized and even persecuted by the Swedish administration. Only since 1999 it gained the national minority status, which resulted in legal protection from the government and farther integration possibilities for the community that suffered social, political and cultural exclusion in the past. Sweden is perceived presently as country with one of the best Roma integration policy, reaching far beyond the EU minimal standards. Malmö is that Swedish city that may play as a pattern for the effective, successful inclusive approach towards Roma community. The discussed solutions implemented by the city council can play as example of conditions to be followed in order to successfully integrate Roma people.
}

Słowa kluczowe: Romowie, polityka integracyjna, mniejszości narodowe w Europie, dyskryminacja

Key-words: Roma, integration policies, national minorities in Europe, discrimination 


\section{WPROWADZENIE}

Romowie w Szwecji pod względem prawnym należą do historycznych mniejszości narodowych (obok Saamów, Żydów, Finów szwedzkich i Finów tornedalskich), które stanowią nieco ponad $0,5 \mathrm{mln}$ obywateli ${ }^{1}$. Uzyskali oni status mniejszości narodowej w grudniu 1999 r. Było to wydarzenie przełomowe przede wszystkim ze względu na uznanie mniejszości narodowych za ludność autochtoniczną, a ich kultur za szwedzkie dziedzictwo narodowe. Jak podkreśla Leena Huss: $Z$ perspektywy europejskiej Szwecja od dawna byta wyjatkiem, ponieważ jej wysitki byty skoncentrowane na imigrantach i jezzykach imigrantów, podczas gdy jej historyczne mniejszości byty w znacznym stopniu ignorowane ${ }^{2}$.

Liczba Romów w Szwecji nie jest dokładnie znana, ale można przypuszczać, że jest to ok. 40-50 tys. osób ${ }^{3}$, co stanowi największą populację tej grupy narodowej w krajach nordyckich. Szwedzkie władze dzielą populację romską na pięć grup ${ }^{4}$ : szwedzcy Romowie - przede wszystkim Kełderasze, Czurarowie (Čurari) i Lowarzy; fińscy Romowie (Kaale), którzy przybyli do Szwecji w XVI w., zostali deportowani na tereny dzisiejszej Finlandii i mogli powrócić dopiero w latach 60. XX w.; trawelerzy, czyli Romowie wędrowni, którzy mogą być potomkami pierwszych Romów przybyłych do Skandynawii lub potomkami Romów przybyłych do Szwecji wraz z niemieckimi i francuskimi wojskami w XVII w.; nienordyccy Romowie - przedstawiciele grup językowych Vlah, jak i innych, znaczną część tej grupy stanowią Romowie przybyli z Polski i innych państw bloku wschodniego w latach 60. i 70. XX w.; nowo przybyli Romowie - głównie uchodźcy z Jugosławii i Kosowa, uciekający przed trwającą tam wojną (przede wszystkim Erli i Gurbetowie)5. Dwie ostatnie kategorie Romów nie są ludnością autochtoniczną w Szwecji, ale uzyskały taki sam status jak pozostałe grupy Romów i uznawane są również za szwedzką mniejszość narodową. Podział na wyżej

$1 \quad$ E. Muciek, Nowe mniejszości w procesie ksztaltowania spoteczeństwa wielokulturowego na przyktadzie Szwecji, [w:] Mniejszości narodowe w państwach Unii Europejskiej. Stan prawny i faktyczny, red. E. Godlewska, M. Lesińska-Staszczuk, Lublin 2013, s. 135.

2 L. Huss, The National Minority Languages in Sweden, [w:] The Other Languages of Europe. Demographic, Sociolinguistic and Educational Perspectives, red. G. Extra, D. Gorter, Clevedon 2001, s. 138, Multilingual Matters.

3 Należy pamiętać, że są to dane tylko szacunkowe, jednak wydaje się, że ta liczba jest realna w odróżnieniu np. od danych European Roma Rights Centre, które w 2011 r. szacowało populację Romów w Szwecji na ok. 15-20 tys.

4 Podział ten został przyjęty przez szwedzką administrację i jest używany w oficjalnych dokumentach. Nazwy poszczególnych grup są w dużym stopniu uproszczone i określają przede wszystkim fale migracji poszczególnych społeczności romskich do Szwecji. Jest to dosłowne tłumaczenie, które musi budzić niejednokrotnie konsternację, gdy zastanowimy się, na jakiej zasadzie pewne grupy Romów określane są jako „szwedzkie”, inne zaś jako „nienordyckie”.

5 The Delegation for Roma Issues, Statens Offentliga Utredningar, Ju 2006:10, s. 6-7, [online] http:// arkiv.minoritet.se/romadelegationen/www.romadelegationen.se/dynamaster/file_archive/080924/ 8649012cecd4affc58173c3a2dcbfc84/Infofolder_engelsk_080904.pdf, 18 VIII 2013. 
wymienione grupy został stworzony przez szwedzką administrację w oparciu o okresy migracji poszczególnych grup do Szwecji. Nie pokrywa się on jednak bardzo często z indywidualną czy grupową identyfikacją poszczególnych członków romskiej społeczności. Należy podkreślić, że populacja romska w Szwecji jest bardzo zróżnicowana pod względem językowym, wyznaniowych czy pochodzenia. Uznaje się, że w Szwecji używa się trzynastu-czternastu dialektów języka romskiego, które są chronione przez państwo jako jeden język ${ }^{6}$. Tak duże zróżnicowanie tej populacji może powodować fragmentaryzację i problemy z reprezentacją interesów tej grupy. Także proces integracji jest znacznie utrudniony w porównaniu z grupami homogenicznymi.

\section{ZARYS HISTORII ROMÓW W SZWECJI}

Romowie przybyli do Skandynawii na początku XVI w. W Kronice szwedzkiej Olausa Petriego w $1512^{7}$ r. znajduje się wzmianka o pojawieniu się ludzi zwanych Tatarami ${ }^{8}$. Tak nazywano Romów w Szwecji nawet do XVII w. Grupa ta nie dotarła do Szwecji drogą lądową, ale przypłynęła z Wielkiej Brytanii'. Początkowo stosunki z przybyłymi układały się poprawnie, jednak już król Gustaw I, stosujący początkowo łagodną politykę w stosunku do Romów, w latach 40. XVI w. rozpoczął prześladowania nowo przybyłych. Jego następcy kontynuowali tę politykę. Także kościół nie akceptował tej społeczności, księża mieli zakaz jakichkolwiek kontaktów z Romami, nie mogli legalnie chrzcić ich dzieci czy grzebać zmarlych ${ }^{10}$. Nie wszyscy duchowni podporządkowali się temu zarządzeniu, ale oficjalnie zakaz odwołano dopiero w $1686 \mathrm{r} .{ }^{11}$ Romowie w tym okresie nie cieszyli się sympatią szwedzkiego społeczeństwa. Grupy romskie spychane były na wschód, na mniej zaludnione i mniej urodzajne ziemie. Niepoddanie się polityce przesiedleń mogło grozić nawet śmiercią zgodnie z przyjętym w $1637 \mathrm{r}$. prawem $^{12}$. W XVII i pierwszej połowie XVIII w. Romowie stali się grupą, którą objęły próby wprowadzania praw skierowanych na walkę z biedą i włóczęgostwem. W okresie tym osoby niezatrudnione mogły być przymusowo wcielane do wojska, co spotka-

6 S. Lipott, The Roma as a Protected Minority? Policies and Best Practices in the EU, „Romanian Journal of European Affairs" 2012, Vol. 12, nr 4, s. 92.

7 Wśród badaczy nie ma zgody co do dokładnej daty pojawienia się pierwszej wzmianki o Romach w szwedzkich kronikach. Montesino, powołując się podobnie jak Fraser na kronikę Petriego, wymienia datę 1520, a nie jak Fraser 1512, Banaś zaś pisze o 1521 r. Zob.: N. Montesino, The „Gypsy Question” and the Gypsy Expert in Sweden, „Romani Studies 5” 2001, Vol. 11, nr 1, s. 4, [online] http://dx.doi. org/10.3828/rs.2001.1; M. Banaś, Między duma a zawstydzeniem - fińscy Romowie $w$ dialogu międzykulturowym, [w:] Tożsamość kulturowa Romów w procesach globalizacji, red. T. Paleczny, J. Talewicz-Kwiatkowska, Kraków 2008, s. 121.

8 A. Fraser, Dzieje Cyganów, przeł. E. Klekot, Warszawa 2001, s. 102.

9 L. Mróz, Od Cyganów do Romów. Z Indii do Unii Europejskiej, Warszawa 2007, s. 72-73.

10 A. Fraser, Dzieje..., s. 103.

11 Tamże, s. 144.

12 M. Banaś, Między dumą a zawstydzeniem..., s. 121. 
ło wielu Romów. Pod koniec XVIII w. polityka państwa w stosunku do Romów ulega złagodzeniu. Przepisy z 1772 r. określały, że Cyganie powinni stać się częścią osiadłej populacji pracującej, co nie pociągnęło jednak za sobą żadnych praktycznych konsekwencji ${ }^{13}$. W późniejszym okresie Romowie byli utożsamiani z włóczęgami i objął ich szereg przepisów dotyczących tej kategorii obywateli, często mających charakter dyskryminacyjny. W 1914 r. przyjęto prawo zabraniające Romom wjazdu do Szwecji, które obowiązywało aż do $1954 \mathrm{r}$.

Na początku XX w. Romowie byli postrzegani przez administrację publiczną jako grupa upośledzona. Kategoria ta zaczęła być stosowana w stosunku do Romów i imigrantów przez pracowników społecznych i przedstawicieli administracji szczególnie po II wojnie światowej, co było związane z nową falą imigracji do Szwecji1 ${ }^{14}$. Stosowanie jej miało służyć odpowiedniemu zdiagnozowaniu grup potrzebujących, zastosowaniu działań przeciwdziałających ich wykluczeniu lub naprawczych, umożliwiających normalne funkcjonowanie grup upośledzonych. Przynależność do tej kategorii wynikała zdaniem ekspertów i urzędników z kultury tej grupy. Etnolodzy i eksperci spoteczni widzieli przyczyny ubóstwa tej grupy [Romów] w „dekadenckiej cygańskiej kulturze”, która nie byta w stanie zaadaptować się do wymogów nowoczesnego spoteczeństwa ${ }^{15}$. Romowie otrzymali status grupy upośledzonej ze względu na uzależnienie od pomocy społecznej, brak zabezpieczenia socjalnego i finansowego. Nawet dorośli członkowie tej grupy zdolni do wykonywania pracy zostali włączeni do tej kategorii ze względu na niemożność aktywizowania na rynku pracy, co argumentowano ich brakiem podstawowej wiedzy niezbędnej do zrozumienia ich nowej sytuacji ${ }^{16}$. W późniejszym okresie stosowanie kategorii grupy upośledzonej wiązało się z chęcią wdrażania przez służby społeczne tzw. sprawiedliwości dystrybutywnej, zrównującej szanse grup mniejszościowych, wykluczonych z pozostałą częścią szwedzkiego społeczeństwa. Po II wojnie światowej Romowie otrzymali oficjalnie status obywateli i działania szwedzkiej administracji zaczęły zmierzać w stronę włączenia ich w nurt życia społecznego. Jednak warto podkreślić, że większość przedstawicieli administracji szwedzkiej obwiniała o złą sytuację tej grupy ich własną kulturę. Jak podkreśla Norma Montesino: wszelkie problemy pojawiajace się w procesie implementacji mechanizmów integracyjnych miaty być zawsze powodowane przez samych Cyganów ${ }^{17}$. Rozwiązaniem tzw. Gypsy question ${ }^{18}$ miała być całko-

13 N. Montesino, The „Gypsy Question”..., s. 4.

14 Taż, Social Disability: Roma and Refugees in Swedish Welfare, "International Journal of Migration, Health and Social Care" 2012, Vol. 8, nr 3, s. 135-141, [online] http://dx.doi. org/10.1108/17479891211267320.

15 Tamże, s. 141.

16 Tamże, s. 142.

17 Taż, The „Gypsy Question”..., s. 3.

18 Odpowiednim tłumaczeniem tego terminu na język polski byłoby zapewne „cygański/romski problem”. Jest to koncepcja, która nie dotyczy bezpośrednio Romów, a raczej skupia się na wizji całości społeczeństwa. Zachodnie społeczeństwo jest modelem organizacji życia społecznego, do którego pewne grupy niekoniecznie przystają. Wizja społeczeństwa wyrażana poprzez tę koncepcję nie uznaje Romów za obcych. Należy dążyć do transformacji tej grupy w użytecznych obywateli, co wymaga specjalnych 
wita asymilacja Romów przeprowadzana przede wszystkim poprzez system edukacji, zatrudnienie i osiedlanie tej populacji. W 1958 r. Parlament wyasygnował specjalne środki finansowe na ten cel. Przez kolejne 20 lat wprowadzania tej polityki sukces można było odnotować jedynie w zakresie mieszkalnictwa, pozostałe dwa obszary, pomimo asygnowanych środków, nie poprawiły się w znaczący sposób.

Polityka w stosunku do Romów zmieniła się znacząco dopiero w latach 70., kiedy rozpoczęła się powolna współpraca ze środowiskami romskimi, a negatywne wypowiedzi na temat kultury romskiej zostały stonowane. W debacie publicznej do głosu zaczęli dochodzić przedstawiciele społeczności romskiej, m.in. Katarina Taikon ${ }^{19}$, która sprzeciwiała się postrzeganiu Romów jako grupy bezsilnej, której może pomóc jedynie rząd, jako że tylko przedstawiciele administracji mieli wiedzieć, w jaki sposób rozwiązać ich problemy. W tym czasie wprowadzono nową politykę w stosunku do Romów, która miała się opierać na tzw. projektach romskich, skierowanych przede wszystkim na pomoc dzieciom w szkole i aktywizację zawodową dorosłych. Rozpoczą się otwarty dialog pomiędzy administracją państwową a przedstawicielami tej mniejszości, co przyczyniło się do instytucjonalizacji romskich przedstawicieli i rzeczników ${ }^{20}$. Jednak dopiero pod koniec lat 80. Romowie mogli zacząć partycypować w procesie podejmowania decyzji dotyczących mniejszości romskiej na różnych szczeblach administracji.

\section{DYSKRYMINACJA ROMÓW}

Jak podkreśla David Thurfjell, bardzo trudno jest określić stopień dyskryminacji Romów w Szwecji. Analizował on liczbę spraw trafiających do policji i innych urzędów państwowych. W ciągu 16 lat, pomiędzy 1986 a 2001 r. do Rzecznika Praw Obywatelskich wpłynęło w sumie pięćdziesiąt skarg na dyskryminację Romów. W kolejnych latach liczba spraw stale wzrastała i tylko w 2003 r. wyniosła czterdzieści ${ }^{21}$. Wzrost liczby zgłoszeń mógł wynikać z wyższej świadomości osób dyskryminowanych o możliwości raportowania o sytuacjach dyskryminacji, jednak należy pamiętać o występowaniu tzw. ciemnej liczby przestępstw, której oficjalne statystyki nie obejmują. Zapewne liczba przypadków dyskryminacji tej grupy narodowej jest znacznie zaniżona

nakładów ze względu na to, iż sami Romowie nie rozumieją, co jest dla nich dobre. W działaniach należy skupić się przede wszystkim na dzieciach, a proces zmiany będzie stopniowy i powolny. Termin gypsy question był używany w Szwecji przez naukowców, przedstawicieli władzy i w debacie publicznej od końca XIX w. Jak podkreśla Montesino nie jest on już oficjalnie używany, jednak jego oddziaływanie jest nadal bardzo silne. Zob. szerzej: N. Montesino, The „Gypsy Question”..., s. 2-3.

19 Informacje na temat działalności Kateriny Taikon na rzecz społeczności romskiej można znaleźć na: Katarina "Katitzi" Taikon and Her Immortal Tale of the Swedish Roma, Romedia Foundation, 8 III 2012, [online] http://romediafoundation.wordpress.com/2012/03/08/katarina-katitzi-taikon-and-her-immortal-tale-of-the-swedish-roma, 28 VIII 2013.

20 W 1973 r. powołano jedną z najważniejszych organizacji romskich w Skandynawii, Nordycką Radę Cyganów, przekształconą później w Romską Federację Narodową (Romernas Riksförbund).

21 D. Thurfjell, Faith and Revivalism in a Nordic Romani Community. Pentecostalism Amongst the Kaale Roma of Sweden and Finland, London 2013, s. 53-54, Library of Modern Religion, 21. 
w oficjalnych statystykach, biorąc pod uwagę niechęć dużej części jej przedstawicieli do zgłaszania nadużyć oficjalnym władzom. Jest to naturalny mechanizm w przypadku grup wykluczonych, których członkowie nie czują w wystarczającym stopniu opieki ze strony administracji państwowej, czego wynikiem jest brak szacunku i zaufania do przedstawicieli władzy na wszystkich szczeblach. Według badaczy dyskryminacji mniejszości w Szwecji: W kontakcie Romów z wtadzami istnieje relacja większośćl mniejszość, zwiąana z nierównym podziatem wtadzy na korzyść pracownika socjalnego, policjanta etc. ${ }^{22}$ Brak zaufania do administracji może być podyktowany wieloletnią polityką dyskryminacyjną stosowaną przez państwo w stosunku do tej grupy. Jak podkreśla Sayali Patwardhan, taki stosunek romskiej społecznosci jest rezultatem dtugiej historii bolesnej dyskryminacji, odmowy dostępu do edukacji, zabierania dzieci romskich z rodzin przez agencje państwowe, przymusowych sterylizacji dokonywanych na kobietach romskich i podobnych innych zabiegów wymierzonych w nich ${ }^{23}$. Dyskryminacja Romów w Szwecji jest widoczna w różnych aspektach życia społecznego. Najważniejsze obszary wykluczenia tej społeczności warto pokrótce opisać.

Jednym z poważniejszych problemów Romów w Szwecji jest mieszkalnictwo. Do lat 60. XX w. Romowie prowadzili najczęściej wędrowny tryb życia, motywowany głównie względami ekonomicznymi. Romowie oferowali bowiem szereg usług przede wszystkim rzemieślniczych i gdy w danym miejscu popyt na ich towary się wyczerpywał, przenosili się w inne miejsce. Od lat 60. pojawiła się tendencja do osiedlania wędrownych mieszkańców, co przełożyło się na oficjalną polityką administracji publicznej. Szereg programów miał umożliwić Romom osiedlenie się na stałe w jednym miejscu. Jednak proces ten nie zawsze przebiegał bez oporów i samych Romów, i mieszkańców terenów, na których planowano osiedlić romską populację. Należy podkreślić, że pomimo upływu wielu lat problem dostępu do mieszkań dla Romów, a także grup imigranckich w Szwecji jest nadal dość widoczny. Grupy te często spychane są do konkretnych, najczęściej peryferyjnych dzielnic, co prowadzi do gettoizacji terytorialnej miast. W dzielnicach takich zanika również poczucie więzi społecznych, rozpoczyna się ich powolna degradacja i wzrasta poziom przestępczości. Brak jest odpowiedniej infrastruktury oraz próby budowania zaufania społecznego pomiędzy reprezentantami poszczególnych grup, często w znaczący sposób różniących się kulturowo.

Nadal poważnym problemem pozostaje edukacja romskich dzieci. System edukacji w Szwecji został dla nich otwarty dopiero pod koniec lat 60. XX w., po kilkunastoletnich staraniach ze strony przedstawicieli romskiej społeczności ${ }^{24}$. Zauważa się stałą tendencję

22 L. Lindgren, H. Pikkarainen, Discrimination against Roma in the Swedish Social System, „Roma Rights Quarterly"2007, nr 4, s. 23.

23 S. Patwardhan, Integration of the Roma in the Swedish Society through the Medium of Primary Education: The Case of Gothenburg MA dissertation, University of Gothenburg, Roehampton University, University of Tromsø, 2011, [online] http://munin.uit.no/bitstream/handle/10037/3503/thesis. pdf ?sequence=1, 26 IX 2013.

24 Discrimination of national minorities in the educational system, Ombudsmannen mot etnisk diskriminering, Report no. 2008:2, s. 21, [online] http://www.do.se/Documents/material-gamla-ombudsman/dorapport-nationella-minoriteter-engelska.pdf, 19 VIII 2013. 
wzrostową w partycypacji tej grupy w systemie edukacji, jednak wciąż pojawiają się poważne problemy w procesie kształcenia romskich dzieci. Jest to przede wszystkim wysoka absencja uczniów, brak odpowiedniej komunikacji pomiędzy rodzicami a nauczycielami, porzucanie edukacji przez starsze dzieci romskie (najczęściej na etapie szóstej klasy) ${ }^{25}$. Dzieci romskie w szkołach są często prześladowane przez rówieśników, a ich rodzice jako jedyną możliwość zapewnienia im bezpieczeństwa uznają pozostanie w domu, pod ich opieką. Także wieloletni brak dostępu do edukacji i brak wykształcenia u licznych dorosłych spowodował niechęć tej grupy do partycypacji w systemie szkolnictwa. Sytuacja ta jednak ulega zmianie i jak wskazują badania, większość Romów (56\%) uznaje ochronę ich praw na polu systemu edukacji za dobrą ${ }^{26}$. Niestety nadal zauważa się brak w programach nauczania czy w ogólnie rozumianym środowisku szkolnym informacji na temat kultury, historii i tradycji Romów. Poważnym problemem jest też nauczanie w języku romani, ze względu na brak odpowiednio przygotowanych nauczycieli, istnienie wielu dialektów i fakt, że język ten nie posiada znormalizowanej, ujednoliconej formy pisanej.

Sytuacja Romów na rynku pracy jest wciąż bardzo skomplikowana. Duży odsetek bezrobotnych wynika na pewno z braku odpowiedniego wykształcenia, ale też z dyskryminacji, jakiej doświadczają ze strony pracodawców. Także sytuacja zdrowotna Romów jest znacznie gorsza niż wśród reszty społeczeństwa ${ }^{27}$. Jak wskazuje badanie z 2011 r. dotyczące oceny własnej sytuacji zdrowotnej wśród Romów, oceniają oni swój stan zdrowia znacznie gorzej niż reszta szwedzkiej populacji ${ }^{28}$. Autorzy badania zauważają, że Sytuacja zdrowotna ludności romskiej jest wynikiem ich sytuacji życiowej, która charakteryzuje sie wysoka stopa bezrobocia, wykluczeniem z gtównego nurtu spoteczeństwa, bezsilnościa i dyskryminacją ${ }^{29}$. Pomimo istniejących ciągle przejawów dyskryminacji, przede wszystkim w obszarze mieszkalnictwa, edukacji, ochrony zdrowia, szwedzka polityka integracyjna wobec Romów przynosi w ostatnich latach dobre rezultaty i znacząco wpływa na poprawę sytuacji tej grupy.

\section{SZWEDZKA POLITYKA INTEGRACYJNA W STOSUNKU DO ROMÓW}

Obecna szwedzka polityka integracyjna wobec Romów opiera się na powoływaniu instytucji, wypracowywaniu rozwiązań, a następnie ich wdrażaniu na poziomie ogólno-

25 D. Thurfjell, Faith..., s. 55-57.

26 S. Lipott, The Roma..., s. 93.

27 Szczegółowe informacje na temat przejawów i skali dyskryminacji Romów w Szwecji można znaleźć m.in. w raporcie szwedzkiego Rzecznika ds. Dyskryminacji: Diskriminering av romer i Sverige: Rapport frian DO:s projekt ären 2002 och 2003 om àtgärder for att forrebygga och motverka etnisk diskriminering av romer, Ombudsmannen mot etnisk diskriminering, Stockholm 2003, [online] http://www.do.se/Documents/material-gamla-ombudsman/romarapportensv05.pdf.

28 S. Hassler, L. Eklund, Sense of Coherence and Self-reported Health among Roma People in SwedenA Pilot Study, „International Journal of Circumpolar Health” 2012, Vol. 71, [online] http://dx.doi. org/10.3402/ijch.v71i0.18438.

29 Tamże. 
narodowym, regionalnym i lokalnym. Wszystkie działania w tym zakresie w ostatnich latach polegają na włączaniu społeczności romskiej na kolejnych etapach realizacji polityki integracyjnej, a także mają charakter ciągły i długofalowy. Polityka integracyjna opiera się na rekomendacjach Unii Europejskiej, dotyczących polityki w stosunku do mniejszości narodowych i etnicznych oraz grup wykluczonych, niejednokrotnie wykraczając znacznie dalej niż zobowiązania wynikające z unijnych dyrektyw ${ }^{30}$.

W 1999 r. rząd szwedzki oficjalnie uznał Romów za jedną z historycznych mniejszości narodowych, co jak już zostało zasygnalizowane, otworzyło drogę do szerszej integracji tej społeczności, uznania jej dziedzictwa kulturowego i walki z marginalizacją jej przedstawicieli w wymiarze politycznym, kulturowym i społecznym. W 2002 r. powołano do życia Radę Romów, instytucję doradczą rządu na poziomie narodowym. W jej składzie znaleźli się przede wszystkim przedstawiciele romskich organizacji ogólnonarodowych, przedstawiciele rządu i wybrani ministrowie, Rzecznik ds. Dyskryminacji i przedstawiciele administracji regionalnej i lokalnej. Rada miała wypracować rekomendacje i propozycje zmian legislacyjnych skierowanych na walkę z dyskryminacją i marginalizacją Romów.

W 2007 r. rząd powołał Delegację ds. Romów, która zastąpiła Radę Romów i która ma pełnić funkcje doradcze dla administracji. W jej skład wchodzi dziesięciu członków, z czego połowa jest romskiego pochodzenia. Delegacja stanowczo potępiła istniejący do tej pory pogląd, że zła sytuacja społeczna społeczności romskiej jest wynikiem ich sposobu życia czy braku edukacji, a stwierdziła mianowicie, że jest ona wynikiem wieloletniej dyskryminacji grupy i wykluczenia jej z głównego nurtu życia społecznego. Celem Delegacji jest promowanie praw Romów i walka z kulturową, społeczną i polityczną marginalizacją tej grupy. Prace Delegacji przebiegają w oparciu o szeroko zakrojone konsultacje z licznymi organizacjami romskimi o charakterze ogólnonarodowym, lokalnym oraz z przedstawicielami administracji państwowej. Powołanie tej instytucji było reakcją na powtarzającą się we wcześniejszych latach krytykę dyskryminacji Romów w Szwecji ze strony Komisji Europejskiej i szwedzkiego Rzecznika ds. Dyskryminacji. W 2010 r. powstał pierwszy raport z jej prac, a rekomendacje w nim zawarte doprowadziły do opublikowania w 2010 r. (angielskojęzyczna wersja - 2011 r.) przez biuro Rzecznika ds. Dyskryminacji opracowania pt. Roma rights. Discrimination, path of redress and how the law can improve the situation of Roma ${ }^{31}$, który stał się dokumentem wyjściowym dla stworzenia całościowej strategii rządu dotyczącej integracji Romów. W lutym 2012 r. rząd szwedzki przyjął dwudziestoletnią "Strategię spo-

30 W artykule nie zostanie zaprezentowana polityka integracyjna Romów na poziomie europejskim, a jedynie polityka integracyjna realizowana w Szwecji. O kształcie unijnej polityki integracyjnej Romów zob. szerzej: J. Talewicz-Kwiatkowska, Wptyw aktywności finansowej Unii Europejskiej na potożenie spoteczne Romów w Polsce, Kraków 2013, Varia Culturalia; J. Szymańczak, Dziatania Unii Europejskiej na rzecz Romów, „Analizy BAS” 2012, nr 3; J.-P. Liégeois, The Council of Europe and Roma. 40 Years of Action, Strasbourg 2012.

31 Roma rights. Discrimination, path of redress and how the law can improve the situation of Roma, Swedish Equality Ombudsman, 2011, [online] http://www.do.se/Documents/sprak/english/Roma\%20 rights.pdf, 19 VIII 2013. 
łecznego włączenia Romów”. Jej celem jest prowadzenie takiej polityki integracyjnej w stosunku do Romów, aby za 20 lat szanse romskiego dwudziestolatka były identyczne z szansami jego rówieśników pochodzących z innych grup narodowych czy etnicznych zamieszkujących Szwecję. Implementacja strategii ma przebiegać przy aktywnym udziale członków społeczności romskiej, nie tylko w charakterze konsultacyjnym, ale też jako bezpośrednich inicjatorów działań. Na lata 2012-2015 z budżetu państwa przeznaczono $46 \mathrm{mln}$ koron na wdrażanie strategii. W $2012 \mathrm{r}$. rozpoczął się pilotażowy program implementacji strategii na poziomie gminnym, założono bowiem, że to administracja lokalna najlepiej potrafi zdiagnozować problemy społeczności romskiej i ma często wieloletnie doświadczenie we współpracy z członkami tej grupy ${ }^{32}$. Programem zostały objęte: Göteborg, Helsingborg, Linköping, Luleå oraz Malmö. Warto również wspomnieć, że jednym z celów strategii jest powołanie Komisji Prawdy i Pojednania, która ma zbadać sytuację Romów w Szwecji w XX w. i odkryć ciemne karty historii dyskryminacji i prześladowania tej grupy narodowej. Jest to spory przełom, jeżeli chodzi o konstruowanie szwedzkiej polityki historycznej, w której do tej pory unikano podejmowania wstydliwych, niewygodnych tematów.

Integracja Romów w Szwecji na poziomie legislacyjnym jest bardzo daleko posunięta i może stanowić wzorzec rozwiązań w tym względzie dla innych państw europejskich. Instytucje odpowiedzialne za integrację Romów na poziomie ogólnonarodowym bardzo dobrze sprawdziły się szczególnie pod względem włączania w swoje prace społeczności romskiej. Sama implementacja założeń polityki integracyjnej, choćby „Strategii inkluzji Romów”, jest na początkowym etapie, choć odnosi już pewne sukcesy, co zostanie wykazane na przykładzie Malmö. Jednak nadal pojawiają się pewne problemy, które zaburzają proces implementacji polityki integracyjnej.

W ostatnich latach w Szwecji pojawił się problem nowych romskich imigrantów z Bułgarii i Rumuni. Nie są oni objęci pomocą społeczną państwa i najczęściej utrzymują się z żebractwa. Powoduje to liczne konflikty i problemy społeczne, a także wpływa negatywnie na wizerunek rodzimych Romów w oczach szwedzkiej populacji. Sytuacja ta doprowadziła w 2010 r. do przypadków nielegalnych deportacji nowo przybyłych Romów (często posiadających obywatelstwo UE) w oparciu o przepisy wymagające od imigrantów posiadania środków finansowych umożliwiających utrzymanie się ${ }^{33}$. Wydarzenia te doprowadziły do dyskusji na temat sytuacji nowych romskich imigrantów, a także spotkały się z negatywnym odbiorem wśród szwedzkich organizacji romskich.

We wrześniu 2013 r. szwedzkie media doniosły o istnieniu nielegalnego rejestru Romów, stworzonego przez policję w Skanii. Miał on obejmować nie tylko przedstawicieli społeczności romskiej podejrzanych o popełnienie czynów przestępnych, ale również osoby niewykazujące tendencji do tego typu zachowań, w tym dzieci

32 A strategy for Roma inclusion 2012-2032, Fact Sheet, Ministry of Employment, II 2012, [online] http://www.government.se/content/1/c6/18/82/46/409e3fdb.pdf, 19 VIII 2013.

33 T. Ullman, Romani People Are Deported without Legal Reason, "Stockholm News” 2010, 30 VII, [online] http://www.stockholmnews.com/more.aspx?NID=5731, 17 IX 2013. 
(ponad 1000). Rejestr miał być tworzony w oparciu o pochodzenie etniczne, co jest zakazane w Szwecji i stanowi jawną dyskryminację danej grupy. Informacja ta wywołała skandal i odbiła się głośnym echem w szwedzkich i międzynarodowych środkach masowego przekazu. Prokuratura rozpoczęła dochodzenie, a czołowi politycy partii rządzącej włączyli się w dyskusję na temat dyskryminacji Romów i rasizmu. Już kilka dni po ujawnieniu informacji Minister Sprawiedliwości Beatrice Ask przeprosiła szwedzkich Romów i stwierdziła: Są bardzo jasne przepisy określające, co jest istotne. Jeśli tworzy się cate drzewa genealogiczne osób o pewnym pochodzeniu etnicznym, w sposób, który jest daleki pracy operacyjnej policji - to jest to oburzające ${ }^{34}$. Niewątpliwie sytuacja ta położyła się cieniem na wizerunku nie tylko szwedzkiej policji, ale też organów odpowiedzialnych za wdrażanie polityki integracyjnej w stosunku do Romów. Jednak szybka i zdecydowana reakcja czynników rządowych oraz oburzenie opinii publicznej świadczą o wysokiej świadomości antydyskryminacyjnej w Szwecji i braku akceptacji dla społecznego wykluczania pewnych grup.

\section{DOBRE PRAKTYKI - MALMÖ}

Malmö jest jednym z miast, w których wdrażana jest obecnie „Strategia społecznego włączenia Romów”. Administracja lokalna prowadzi jednak od kilku lat własną, unikalną i bardzo skuteczną politykę integracyjną Romów. Model integracyjny realizowany przez władze miasta jest określany mianem modelu Malmö i stanowi przykład dobrych praktyk realizowanych w ramach polityki integracyjnej na szczeblu lokalnym.

Malmö liczy 300 tys. mieszkańców, z czego 29\% stanowi ludność o nieszwedzkim pochodzeniu, wywodząca się ze 174 różnych narodowości ${ }^{35}$. Miasto ma też bardzo młodą populację, gdyż $48 \%$ ludności nie przekroczyło trzydziestego piątego roku życia ${ }^{36}$. Jest miastem wysoko zindustrializowanym, o upadłym przemyśle, z wysoką stopą bezrobocia i dużą populacją migrantów. Czynniki te tworzą niekorzystne tło demograficzno-społeczne, skutkujące tworzeniem się podziałów terytorialnych wewnątrz miasta, sprzyjające także rozwojowi konfliktów międzyetnicznych. Taka sytuacja jest wynikiem kryzysu gospodarczego, który dotknął miasto na początku lat 90. XX w. Gałęzie przemysłu, które do tej pory stanowiły podstawę gospodarki miasta (głównie przemysł stoczniowy i tekstylny), pogrążyły się w głębokim kryzysie i w rezultacie w znacznej mierze upadły. Od początku XXI w. trwa transformacja lokalnej gospodarki. Miasto przyciąga nowych inwestorów i asygnuje środki na rozwój nowych branż, przede wszystkim nowych technologii, IT. Staje się także prężnym ośrodkiem naukowym. Następuje zmiana charakteru miasta z przemysłowego na

34 Wypowiedź zamieszczona w czasopiśmie „The Local”, zob.: Justice Minister asks Roma for Forgiveness, „The Local” 2013, 25 IX, [online] http://www.thelocal.se/50432/20130925, 25 IX 2013.

35 Dane z kwietnia 2011 r., Malmo.com, [online] http://www.malmo.com/thecity/malmo_brief/ population.asp, 13 VII 2013.

36 Malmo Business, [online] http://www.malmobusiness.com/sites/default/files/filearchive/trade_ industry.pdf, 13 VII 2013. 
„miasto wiedzy”, które dba o rozwój kapitału społecznego i inwestuje w innowacyjne rozwiązania gospodarcze.

Ze względu na znaczny odsetek populacji nieszwedzkiej Malmö ma charakter miasta wielokulturowego. Podstawowym wyzwaniem w związku z zarządzaniem różnorodnością jest tu problem integracji migrantów i mniejszości etnicznych, zapewnienie im równych szans, pomoc $\mathrm{w}$ wyjściu $\mathrm{z}$ analfabetyzmu, ograniczanie bezrobocia oraz gettoizacji. Obecnie bowiem zauważa się znaczną i stale pogłębiającą się segregację przestrzenną mieszkańców, co szczególnie widoczne jest w dzielnicy Rosengård, zamieszkiwanej w $60 \%$ przez ludność o pochodzeniu nieszwedzkim ${ }^{37}$. W działaniach integracyjnych największy nacisk kładziony jest na naukę języka szwedzkiego, jako podstawy społecznego funkcjonowania.

Miasto podejmuje liczne działania edukacyjne na rzecz mniejszości rasowych i etnicznych oraz przeciwdziałania dyskryminacji, w tym programy szkolne oraz program dla kibiców lokalnego klubu. Od 1993 r. w Malmö odbywa się antyrasistowski festiwal filmowy, a 21 marca uroczyście obchodzi się międzynarodowy dzień przeciwdziałania nienawiści i dyskryminacji rasowej. W zakresie budowania świadomości społecznej podmiotów prywatnych wprowadzono do zamówień publicznych klauzulę ograniczającą możliwość ubiegania się o zamówienia publiczne przez podmioty naruszające prawo antydyskryminacyjne. Również koncesje na alkohol przyznawane są pod warunkiem przestrzegania zasady niedyskryminacji. Wygospodarowano środki na szkolenia antydyskryminacyjne personelu administracyjnego oraz wprowadzono zasady polityki równościowej do podstaw funkcjonowania urzędów. Dba się również o zróżnicowaną ofertę kulturalną i zwiększenie uczestnictwa mniejszości w życiu kulturalnym miasta. Miasto prowadzi również forum dialogu, tj. konsultacje z przedstawicielami mniejszości, członkami wspólnot religijnych etc. Malmö realizuje liczne programy integracyjne $e^{38}$ prowadzone najczęściej przez koalicje oraz partnerstwa publiczno-prywatne. Projekty te dzięki poświęceniu i zaangażowaniu wielu podmiotów osiągają bardzo wysoką skuteczność. Motywacją do podejmowania działań na tym polu jest również doroczna, bardzo prestiżowa Nagroda Integracyjna (Integrationspriset) przyznawana przez miasto osobom i instytucjom szczególnie zasłużonym na polu integracji.

Polityka integracyjna wobec Romów jest realizowana w Malmö przez specjalnie w tym celu powołaną instytucję, Romskie Centrum Informacji i Wiedzy (Romskt Informations- och Kunskapscenter) ${ }^{39}$. Jest to miejska instytucja finansowana w sposób ciągły z budżetu miasta, powstała w kwietniu 2009 r., której zadaniem jest integracja

37 M. Banaś, Szwedzka polityka integracyjna wobec imigrantów, Kraków 2010, s. 246-247, Varia Culturalia.

38 Programy te dotyczą przede wszystkim imigrantów, dlatego nie będą szczegółowo omawiane w tekście. Informacje na ich temat, zob.: tamże, s. 249-253.

39 Materiały na temat działalności Centrum zostały zebrane podczas wizyty studyjnej przeprowadzonej 10 I 2013 r. Wizyta odbyła się w ramach projektu „Kraków przeciwko rasizmowi i ksenofobii”, prowadzonemu przez Stowarzyszenie INTERKULTURALNI PL. Celem projektu było zdiagnozowanie najlepszych rozwiązań w ramach polityki lokalnej dotyczących integracji imigrantów 
społeczności romskiej w mieście. W swoich działaniach kieruje się społeczną perspektywą integracji Romów, polegającą na zwiększeniu partycypacji grupy w życiu społeczności lokalnej oraz umożliwieniu jej kontaktu z innymi mieszkańcami miasta na wielu płaszczyznach, jednocześnie troszcząc się o perspektywę systemową poprzez kontrolę nad różnymi instytucjami integracyjnymi i dbaniem, aby ich działania były skoordynowane i skierowane na osiągnięcie wspólnego celu. Centrum stanowi platformę, z której poziomu koordynowane są różnorodne wysiłki na rzecz polepszenia warunków życia społeczności, wykluczonej przez wiele dekad ze szwedzkiego społeczeństwa. Instytucja ta kieruje się podejściem holistycznym i interdyscyplinarnym.

$\mathrm{Z}$ diagnoz Centrum wynika, że największym problemem w integracji społeczności romskiej w Malmö jest brak wiedzy społeczeństwa większościowego o kulturze, tradycji i historii tej mniejszości narodowej. Dlatego działania Centrum są skupione na poszerzaniu wiedzy na ten temat, w celu przełamywania barier i nieufności pomiędzy społecznością romską a resztą populacji. Istotne jest zwalczanie negatywnych stereotypów na temat Romów i możliwość szerszego zaprezentowania ich własnych tradycji w przestrzeni publicznej miasta. Centrum organizuje szereg wydarzeń skierowanych na integrację społeczności romskiej i innych grup. Są to konferencje, spotkania, wykłady przygotowane we współpracy z organizacjami romskimi, innymi organizacjami mniejszościowymi oraz instytucjami administracji lokalnej. W okresie od stycznia do połowy kwietnia 2012 r. odbyło się trzydzieści siedem takich wydarzeń, które miały na celu integrację Romów z mieszkańcami miasta ${ }^{40}$.

Centrum stworzyło innowacyjny model pracy ze społecznością romską, w którym działania integracyjne kontrolują i wypracowują liderzy romscy zatrudnieni w tej instytucji. Samo Centrum zatrudnia także pracowników nieromskich, co pozwala na wymianę doświadczeń oraz wspólne działanie na rzecz zwiększania świadomości co do sytuacji ludności romskiej w społeczeństwie szwedzkim. Powołanie Centrum było istotne ze względu na potrzebę zyskania zaufania, zbudowania wiarygodności, stabilności funkcjonowania i możliwości kontynuowania pracy z tą społecznością. Dzięki temu osiąga się trwałe rezultaty zarówno w pracy indywidualnej, jak i na poziomie strukturalnym. Centrum prowadzi program wsparcia Romów chcących założyć własne organizacje pozarządowe, a także prowadzi we współpracy z urzędem pracy program aktywizacji zawodowej Romów ${ }^{41}$. Oferuje szereg warsztatów zwiększających kompetencje zawodowe i kompetencje w zakresie edukacji międzykulturowej.

Działania Centrum pozwalają na zdobycie unikalnej wiedzy o społeczności romskiej zarówno w sferze teoretycznej, jak i praktycznej, co następnie przekłada się na dobrze dobrane metody pracy i brak trudności komunikacyjnych czy też porozumienia z beneficjentami. Centrum prowadzi badania nad wieloletnią dyskryminacją Romów

i przedstawicieli mniejszości oraz walki z rasizmem i ksenofobią w czterech miastach europejskich. Projekt finansowany był ze środków Fundacji im. Stefana Batorego.

40 Roma Information and Knowledge Center. Social Resource Management, City of Malmö Social Resource Management, Malmö 2012, s. 9-10.

41 Tamże, s. 6. 
w Szwecji i jej wpływem na ich dzisiejszą sytuację społeczną. Zaznacza się bowiem, że marginalizacja i dyskryminacja Romów w przeszłości miały zdecydowany wpływ na współczesną izolację tej społeczności, brak zaufania do administracji publicznej i ograniczone kontakty z innymi grupami etnicznymi czy narodowymi.

Przedstawiciele romscy edukują również pracowników socjalnych oraz służby mundurowe w zakresie obowiązującego prawa mniejszości, historii Romów, ich warunków życia i ekspresji kulturowej. Centrum otwarte jest dla mieszkańców, prowadzi wsparcie indywidualne (asystenturę) w szkołach i w ramach pomocy społecznej. W 2012 r. zatrudniało dwóch doradców edukacyjnych i współpracowało z pięcioma szkołami różnego typu ${ }^{42}$. W przyszłości planowane jest rozszerzenie współpracy na kolejne placówki edukacyjne. Doradcy nie tylko pomagają uczniom mającym problemy szkolne, ale też prowadzą zajęcia dla nauczycieli, pracowników szkół i rodziców. Pomagają rozwiązywać pojawiające się problemy, szczególnie w relacji nauczyciel-rodzic.

Cztery lata funkcjonowania Centrum pokazały, iż tego rodzaju model pracy przynosi znacznie lepsze efekty niż uprzednie projekty integracyjne. Bezpośrednie włączenie Romów w struktury Centrum i wspólna praca z osobami o innym pochodzeniu etnicznym pomagają we wzajemnym poznaniu się i wypracowaniu efektywnej współpracy. Centrum jest częścią magistratu i nie działa na zasadzie projektowej, ale jest finansowane w sposób ciągły przez władze miejskie, co pozwala na osiągnięcie długofalowych efektów pracy. Pomimo szeregu nierozwiązanych kwestii, jak choćby dostęp społeczności romskiej do zasobów mieszkalnych, wiele inicjatyw i programów realizowanych przez tę instytucję przynosi pozytywne rezultaty.

\section{ZAKOŃCZENIE}

Szwedzki model integracji Romów jest jednym z najlepiej rozwiniętych w Europie. Pomimo że polityka integracyjna wobec mniejszości narodowych jest dość nowym zjawiskiem, szwedzkie osiągnięcia $\mathrm{w}$ tym obszarze mogą być przykładem wzorcowych rozwiązań dla innych państw. Wynika to zapewne z długiej historii integracji migrantów w tym kraju. Pomimo zamieszek imigrantów, które wybuchły w kilku miastach szwedzkich w maju 2012 r., i licznych głosów krytyki w stosunku do szwedzkiej polityki integracyjnej wydaje się, że przyniesie ona oczekiwane rezultaty w przyszłości i zdecydowanie ma charakter długofalowy. Warto zauważyć, że wspomniane zamieszki nie dotknęły Malmö, pomimo licznej populacji imigrantów. Może to świadczyć o sukcesie lokalnej polityki integracyjnej i taki wniosek nie jest zbyt daleko idący, jeżeli spojrzy się na nakłady i wysiłki administracji lokalnej we wprowadzaniu polityki równościowej, inkluzywnej. Najlepszym przykładem takiej polityki jest właśnie integracja społeczności romskiej, choć lata prześladowań i duże zróżnicowanie tej społeczności były czynnikami zdecydowanie utrudniającymi proces integracyjny. W Malmö udało się jednak włączyć Romów w pracę nad poprawą ich

42 Tamże, s. 15. 
sytuacji i aktywizować w przestrzeni publicznej i kulturalnej miasta, przez co stali się mniejszością widoczną w mieście, a wkład ich kultury do szwedzkiego dziedzictwa narodowego został doceniony.

\section{BIBLIOGRAFIA}

Banaś M., Między duma a zawstydzeniem - finssy Romowie w dialogu międzykulturowym, [w:] Tożsamość kulturowa Romów w procesach globalizacji, red. T. Paleczny, J. Talewicz-Kwiatkowska, Kraków 2008.

Banaś M., Szwedzka polityka integracyjna wobec imigrantów, Kraków 2010, Varia Culturalia. The Delegation for Roma Issues, Statens Offentliga Utredningar, Ju 2006:10, [online] http:// arkiv.minoritet.se/romadelegationen/www.romadelegationen.se/dynamaster/file_archive /080924/8649012cecd4affc58173c3a2dcbfc84/Infofolder_engelsk_080904.pdf.

Discrimination of national minorities in the educational system, Ombudsmannen mot etnisk diskriminering, Report no. 2008:2, [online] http://www.do.se/Documents/material-gamla-ombudsman/dorapport-nationella-minoriteter-engelska.pdf.

Diskriminering av romer i Sverige: Rapport frän DO:s projekt åren 2002 och 2003 om àtgärder for att forrebygga och motverka etnisk diskiminering av romer, Ombudsmannen mot etnisk diskriminering, Stockholm 2003, [online] http://www.do.se/Documents/material-gamla-ombudsman/romarapportensv05.pdf.

Fraser A., Dzieje Cyganów, przeł. E. Klekot, Warszawa 2001.

Hassler S., Eklund L., Sense of Coherence and Self-reported Health among Roma People in Sweden - A Pilot Study, „International Journal of Circumpolar Health” 2012, Vol. 71, [online] http://dx.doi.org/10.3402/ijch.v71i0.18438.

Huss L., The National Minority Languages in Sweden, [w:] The Other Languages of Europe. Demographic, Sociolinguistic and Educational Perspectives, red. G. Extra, D. Gorter, Clevedon 2001, Multilingual Matters.

Justice Minister asks Roma for Forgiveness, „The Local” 2013, 25 IX, [online] http://www.thelocal.se/50432/20130925.

Katarina "Katitzi" Taikon and Her Immortal Tale of the Swedish Roma, Romedia Foundation, 8 III 2012, [online] http://romediafoundation.wordpress.com/2012/03/08/katarina-kati tzi-taikon-and-her-immortal-tale-of-the-swedish-roma.

Liégeois J.-P., The Council of Europe and Roma. 40 Years of Action, Strasbourg 2012.

Lindgren L., Pikkarainen H., Discrimination against Roma in the Swedish Social System, „Roma Rights Quarterly" 2007, nr 4.

Lipott S., The Roma as a Protected Minority? Policies and Best Practices in the EU, „Romanian Journal of European Affairs" 2012, Vol. 12, nr 4.

Malmö Business, [online] http://www.malmobusiness.com/sites/default/files/filearchive/trade_industry.pdf.

Malmo.com, [online] http://www.malmo.com/thecity/malmo_brief/population.asp.

Montesino N., The „Gypsy Question” and the Gypsy Expert in Sweden, „Romani Studies 5” 2001, Vol. 11, nr 1, [online] http://dx.doi.org/10.3828/rs.2001.1. 
Montesino N., Social Disability: Roma and Refugees in Swedish Welfare, „International Journal of Migration, Health and Social Care" 2012, Vol. 8, nr 3, [online] http://dx.doi. org/10.1108/17479891211267320.

Mróz L., Od Cyganów do Romów. Z Indii do Unii Europejskiej, Warszawa 2007.

Muciek E., Nowe mniejszości w procesie ksztattowania spoteczeństwa wielokulturowego na przyktadzie Szwecji, [w:] Mniejszości narodowe w pansstwach Unii Europejskiej. Stan prawny ifaktyczny, red. E. Godlewska, M. Lesińska-Staszczuk, Lublin 2013.

Patwardhan S., Integration of the Roma in the Swedish Society through the Medium of Primary Education: The Case of Gothenburg, MA dissertation, University of Gothenburg, Roehampton University, University of Tromsø, 2011, [online] http://munin.uit.no/bitstream/handle $/ 10037 / 3503 /$ thesis.pdf ? sequence $=1$.

Roma Information and Knowledge Center. Social Resource Management, City of Malmö Social Resource Management, Malmö 2012.

Roma rights. Discrimination, path of redress and how the law can improve the situation of Roma, Swedish Equality Ombudsman, 2011, [online] http://www.do.se/Documents/sprak/english/Roma\%20rights.pdf.

A strategy for Roma inclusion 2012-2032, Fact Sheet, Ministry of Employment, II 2012, [online] http://www.government.se/content/1/c6/18/82/46/409e3fdb.pdf.

Szymańczak J., Dziatania Unii Europejskiej na rzecz Romów, „Analizy BAS” 2012, nr 3.

Talewicz-Kwiatkowska J., Wptyw aktywności finansowej Unii Europejskiej na potożenie spoteczne Romów w Polsce, Kraków 2013, Varia Culturalia.

Thurfjell D., Faith and Revivalism in a Nordic Romani Community. Pentecostalism Amongst the Kaale Roma of Sweden and Finland, London York 2013, Library of Modern Religion, 21.

Ullman T., Romani People Are Deported without Legal Reason, „Stockholm News” 2010, 30 VII, [online] http://www.stockholmnews.com/more.aspx?NID=5731.

Mgr Jakub KOŚCIÓŁEK - doktorant w Instytucie Studiów Międzykulturowych UJ, ukrainoznawca, kulturoznawca międzynarodowy, absolwent studiów bliskowschodnich, prezes Stowarzyszenia INTERKULTURALNI PL w Krakowie, autor monografii Konflikt w Darfurze (2010), redaktor raportu Cudzoziemcy w Krakowie. Monitoring krakowskich instytucji publicznych pod katem ich dostosowania do potrzeb obcokrajowców mieszkajacych w Krakowie lub go odwiedzajacych (2011), współredaktor pracy Problemy wspótczesnej Afryki. Szanse i wyzwania na przysztość (2013). Stypendysta Fundacji Fulbrighta 2013/2014 na The George Washington University w Waszyngtonie. 